\title{
BUDGET SYSTEM COMPARISON BETWEEN REPUBLIC OF MACEDONIA AND REPUBLIC OF SLOVENIA
}

\author{
Eftimija Dimitrova ${ }^{1}$, Janka Dimitrova ${ }^{2}$ \\ 1 University of London - London, United Kingdom, eftimijadimitrova@yahoo.com \\ 2"Goce Delcev" University - Faculty of Economics - Stip, Republic of North \\ Macedonia, janka.dimitrova@ugd.edu.mk
}

\begin{abstract}
The budget represents an annual plan for financing the functions and responsibilities of one country, the units of local government and the funds, and consists of an annual estimation of revenues and expenditures usually for one fiscal year [1]. It also may include strategic plans. The budget can be classified differently. The budget process may vary between different countries. The budget helps a country to predict if it will have budget surplus or deficit and plan any further financing if needed. The objectives of the budget policy can be: resource allocation, redistribution and economic stabilization.

The purpose of this paper is to analyse and compare the budgets of two different countries, Republic of Macedonia and Republic of Slovenia for the years 2008, 2013 and 2017.

Macedonia and Slovenia are countries that are similar in territory, in terms of population and both were part of the former SFRY. They have been operating as independent states since 1991. This is why they are the target of the analysis of their budget systems in this research paper.
\end{abstract}

Key words: budget, budget system, expenses, local government, revenues

\section{Introduction}

The budget is an act that envisages the revenues and expenditures of the state for a period of one year. The budget is also considered to be an act of the legislature (parliament) which provides for and approves in advance, for a future period (usually one year) the distribution of revenues and expenditures within the financing as well as in relation to the political and social nature. There is an understanding that the budget is a law in the formal sense of the word for preparing budget requests.

The draft budget is prepared and proposed by the administrative bodies. The budget for next year should be adopted by the end of the current year.

If the budget period passes and the budget is not adopted on time, then a way must be found to avoid that irregularity in the budget process: to spend public money without prior approval (adopted budget).

\section{Budget System of Republic of Macedonia}

The budget of Republic of Macedonia is planned for three years, but it is adopted for one fiscal year which is 12 months and starts from January 1 and ends on December 31 [2]. The Ministry of Finance, the government, the parliament and the budget users are the ones that are included in the budget process. The Minister of Finance is responsible for preparing the budget 
of the Republic of Macedonia and its submission to the Government of the Republic of Macedonia. The Parliament is responsible for adopting the budget as a law. The Government determines the strategic priorities for the next year and the budget users are responsible for the preparation of a three-year strategic plan that contains programs and activities for achieving the strategic priorities of the government, the objectives and priorities of the budget user for that period as well as the planned revenues and expenditures for the following year [3].

The budget law regulates the budget process which covers three phases as shown in Table1.

Table 1: Macedonian Budget Process [4]

\begin{tabular}{|c|c|c|c|}
\hline & $\begin{array}{l}1^{S T} \text { Phase - Planning and } \\
\text { budget preparation }\end{array}$ & $\begin{array}{l}2^{N D} \text { Phase - Adoption of } \\
\text { the Budget }\end{array}$ & $\begin{array}{l}3^{R D} \text { Phase - Implementation of } \\
\text { the Budget }\end{array}$ \\
\hline $\begin{array}{l}\frac{8}{9} \\
\omega \\
5 \\
5\end{array}$ & $\begin{array}{l}\text { Strategic priorities of the } \\
\text { government } \\
\text { April 15: The Government } \\
\text { sets out its strategic priorities }\end{array}$ & $\begin{array}{l}\text { Submitting the Draft } \\
\text { Budget to the } \\
\text { Government } \\
\text { November } 1 \text { : The Ministry } \\
\text { of Finance submits the } \\
\text { budget to the Government }\end{array}$ & $\begin{array}{l}\text { Submitting an annual financial } \\
\text { plan } \\
\text { Within } 25 \text { days of adoption of the } \\
\text { budget, the budget users submit to } \\
\text { the Ministry of Finance an annual } \\
\text { plan by quarters } \\
\text { Within } 5 \text { days of the day } \\
\text { the adoption of the budget Each } \\
\text { user unit submits an extract from } \\
\text { the annual financial plan }\end{array}$ \\
\hline $\begin{array}{l}\frac{2}{d} \\
\text { के } \\
0 \\
\text { సे }\end{array}$ & $\begin{array}{l}\text { Preparing the fiscal policy } \\
\text { for the next year } \\
\text { July: The Ministry of Finance } \\
\text { prepares a report on the fiscal } \\
\text { situation and submits it to the } \\
\text { Government }\end{array}$ & $\begin{array}{l}\text { Submitting the } \\
\text { Government Budget } \\
\text { Proposal to the } \\
\text { Parliament } \\
\text { November } 15: \text { The } \\
\text { Government submits the } \\
\text { draft budget to the } \\
\text { Parliament }\end{array}$ & $\begin{array}{l}\text { Submitting a quarterly financial } \\
\text { plan } \\
\text { The latest } 5 \text { days before } \\
\text { beginning of the quarter } \\
\text { The budget users prepare a draft- } \\
\text { financial plan for a given quarter } \\
\text { and submit it to Ministry of Finance } \\
\text { - Treasury Department }\end{array}$ \\
\hline $\begin{array}{l}\frac{2}{9} \\
\text { का } \\
\frac{0}{\infty}\end{array}$ & $\begin{array}{l}\text { Preparation of the budget } \\
\text { circular } \\
\text { April: The Minister of Finance } \\
\text { prepares a budget circular } \\
\text { and submits it to the budget } \\
\text { users } \\
\text { June: Budget users prepare a } \\
\text { draft budget calculation }\end{array}$ & $\begin{array}{l}\text { Consideration of the } \\
\text { Draft Budget before the } \\
\text { Assembly } \\
\text { December: Parliament } \\
\text { discusses the Draft } \\
\text { Budget not later than the } \\
\text { end of December } \\
\text { Parliament adopts the } \\
\text { Budget }\end{array}$ & $\begin{array}{l}\text { Approval of the quarterly } \\
\text { financial plans and execution of } \\
\text { the Budget }\end{array}$ \\
\hline $\begin{array}{l}\frac{8}{8} \\
\omega \\
\bar{z}\end{array}$ & $\begin{array}{l}\text { Delivery of budget requests } \\
\text { June 15: The budget requests } \\
\text { are submitted by the budget } \\
\text { officers to the Ministry of } \\
\text { Finance }\end{array}$ & & \\
\hline $\begin{array}{l}\frac{2}{d} \\
\text { के } \\
\text { हิ }\end{array}$ & $\begin{array}{l}\text { Adjustment of the } \\
\text { requirements of the budget } \\
\text { users } \\
\text { October: The Ministry of } \\
\text { Finance adjusts the needs of } \\
\text { the users with the available } \\
\text { funds in the budget for the } \\
\text { next year. On the basis of this } \\
\text { alignment, the draft budget is } \\
\text { being prepared and the } \\
\text { explanation to the Budget. }\end{array}$ & & \\
\hline
\end{tabular}


The budget of the Republic of Macedonia consists of three sections:

- The general section - contains the total revenues and other inflows and total expenditures and other outflows of the fiscal budget year, as well as global projections of revenues, inflows, expenditures and outflows for the next two years and other data.

- The special section - contains a plan of the approved funds of budget users and funds by programs, subprograms and items for the fiscal year.

- The development section - contains the plans of the development programs of budget users [5].

The budget of Republic of Macedonia, according to the law on budgets, has the following classifications:

- Institutional classification - budget division according to organizational units - budget users. Ex: President of Republic of Macedonia, Ministry of Finance, Government of Republic of Macedonia, Ombudsman, etc.

- Economic classification - division of the budget according to the types of revenues and inflows, and expenditures and outflows. Ex: Tax revenue, Non-tax revenue, Salaries, Capital Expenditures, etc.

- Program classification - is a structure of codes for classifying programs and subprograms determined by the Budget. Ex: Government Program / Subprogram; Budget program / subprogram; Development subprogram;

- Functional classification - division of the budget according to the functions of the central government and municipalities. Ex: Defence, Education, Social Protection, Environmental Protection, etc.

- Sources of funds classification - Primary Budget; Budget of Self-Financial Activities; Budget from Loans and Budget from Donations [6];

\section{Budget System of Republic of Slovenia}

The budget of the Republic of Slovenia is an act of the state, which envisages all revenues and other receipts and expenses and other expenditures of the state for one year. The budget is adopted by the National Assembly according to a special, prescribed procedure [7]. The budget of Slovenia is prepared for two years [8].

The budget of Slovenia is prepared in two phases as shown in Table 2:

Table 2: The budget process of Slovenia [9]

\begin{tabular}{|c|c|c|}
\hline & $1^{\text {ST Phase }}$ & $2^{N D}$ Phase \\
\hline March & $\begin{array}{l}\text { Establishment of macroeconomic } \\
\text { forecasts and overall projections } \\
\text { for revenues, spending, and the } \\
\text { deficit or surplus. The Ministry of } \\
\text { Finance is assisted by the Institute } \\
\text { of Macroeconomic Analysis and } \\
\text { Development }\end{array}$ & \\
\hline April & $\begin{array}{l}\text { Decisions are first made on overall } \\
\text { targets for revenues, outlays, and } \\
\text { deficit/surplus. This is contained in } \\
\text { a memo that is sent out to the } \\
\text { various ministries in April including } \\
\text { the spending ceilings for each }\end{array}$ & \\
\hline May & The Budget Circular is issued & \\
\hline June & & Public agencies prepare their budget requests \\
\hline August & & $\begin{array}{l}\text { By August 15: Submission of the budget } \\
\text { requests by the budget users; } \\
\text { Budget requests reviewed by MoF - } \\
\text { negotiations }\end{array}$ \\
\hline
\end{tabular}




\begin{tabular}{|c|l|l|}
\hline September & $\begin{array}{l}\text { September 15: The Minister of Finance } \\
\text { submits a draft of the state budget for the } \\
\text { coming fiscal year to the cabinet. The cabinet } \\
\text { has until the end of September to agree on the } \\
\text { elements of the budget }\end{array}$ \\
\hline October & $\begin{array}{l}\text { October 1: The budget is submitted to } \\
\text { Parliament. } \\
\text { From October to December: After initial } \\
\text { consideration, Parliament votes on whether to } \\
\text { accept the broad outlines of the government's } \\
\text { budget. If not, it is returned to the MF to submit } \\
\text { a revised version. }\end{array}$ \\
\hline December &
\end{tabular}

The budget is composed of three main parts:

- General part - includes a revenue and expenditure account, a receivable and an investment account, and a financing account.

- Special part - means the content of the use of public funds in the financial plans of individual budget users or groups of budget users and includes expenditure and other operating expenditure presented by policies, major programs and sub-programs.

- Development program plan - expenditure is planned according to the structure of the program classification, individual measures and projects and sources of financing by individual years for the full implementation of projects and measures. It is shown in the budget by project groups and projects, as well as the sources of funds for their implementation [10].

The budget of Republic of Slovenia has the following classifications:

- Institutional classification - Who spend public money? Ex: General government $\rightarrow$ Central government $\rightarrow$ State Funds

- Economic classification - How we spend public money; For which economic purposes?

- Program classification - What for we spend public money; On which program areas? It has 3 levels: Policy, Program and Subprogram. Ex: Labour market, Energy, Health care, Education and sport, etc.

- Functional classification - What for we spend public money; for which function?

- Sources of funds classification - From which funds [11]?

\section{Comparison of the Budgets between Macedonia and Slovenia}

\subsection{Comparison of the Budgets between Macedonia and Slovenia in 2008}

\subsubsection{Budget Balance}

Table 3: Budget Balance of Macedonia and Slovenia in 2008

\begin{tabular}{|c|c|c|}
\hline in euro & \multicolumn{1}{c|}{ MACEDONIA } & \multicolumn{1}{c|}{ SLOVENIA } \\
\hline TOTAL REVENUE & $2,560,134,954.37$ & $15,339,211,373.57$ \\
\hline TOTAL EXPENDITURE & $2,411,846,877.79$ & $15,441,743,040.52$ \\
\hline BUDGET BALANCE & $148,288,076.59$ & $-102,531,666.95$ \\
\hline
\end{tabular}


Graph 1: Budget Balance of Macedonia and Slovenia in 2008

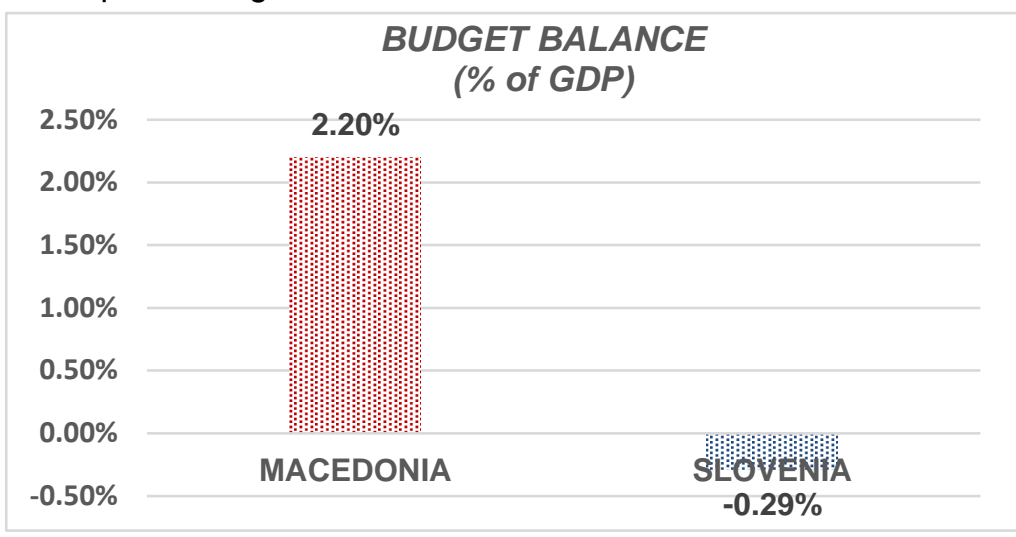

From Table 3 and Graph 1 above, we can see that in 2008 Macedonia was in budget surplus with $2.20 \%$ of the Gross Domestic Product. On the other hand, Slovenia was in budget deficit with $0.29 \%$ of the GDP.

\subsubsection{Total Revenues}

Table 3: Total Revenues of Macedonia and Slovenia in 2008

\begin{tabular}{|l|r|r|}
\hline in euro & \multicolumn{1}{|c|}{ MACEDONIA } & \multicolumn{1}{c|}{ SLOVENIA } \\
\hline TOTAL REVENUE & $2,560,134,954.37$ & $15,339,211,373.57$ \\
\hline TOTAL TAX REVENUE & $1,970,059,788.94$ & $13,937,364,572.81$ \\
\hline NON-TAX REVENUE & $318,713,331.90$ & $854,903,347.53$ \\
\hline CAPITAL REVENUE & $25,446,981.12$ & $117,265,471.54$ \\
\hline DONATIONS RECEIVED & $242,314,818.41$ & $10,387,974.81$ \\
\hline TRANSFERED REVENUES & - & $53,916,240.72$ \\
\hline RECEIPTS FROM THE EU BUDGET & - & $365,373,766.16$ \\
\hline REVENUES FROM REPAYMENT OF LOANS & $3,105,691.06$ & - \\
\hline DOMESTIC BORROWING & $494,342.94$ & - \\
\hline
\end{tabular}

Graph 2: Total Revenues as \% of GDP of Macedonia and Slovenia in 2008

\begin{tabular}{|c|c|c|c|}
\hline \multicolumn{4}{|l|}{ TOTAL REVENUES } \\
\hline \\
\hline \multicolumn{4}{|l|}{ REVENUES FROM REPAYMENT OF...0.12\% } \\
\hline \\
\hline \multirow{2}{*}{\multicolumn{4}{|c|}{$\begin{aligned} \text { TRANSFERED REVENUES } & 0.35 \% \\
\text { DONATIONS RECEIVED } & 9.07 \%\end{aligned}$}} \\
\hline & & & \\
\hline \\
\hline \multicolumn{4}{|l|}{ NON-TAX REVENUE $0.99 \% 5.57 \%$} \\
\hline \multicolumn{4}{|c|}{ TAX REVENUE ${ }_{76.95 \%}{ }^{90.86 \%}$} \\
\hline \multicolumn{4}{|c|}{$\begin{array}{llllll}0.00 \% & 20.00 \% & 40.00 \% & 60.00 \% & 80.00 \% & 100.00 \%\end{array}$} \\
\hline \multicolumn{4}{|c|}{ - SLOVENIA } \\
\hline
\end{tabular}




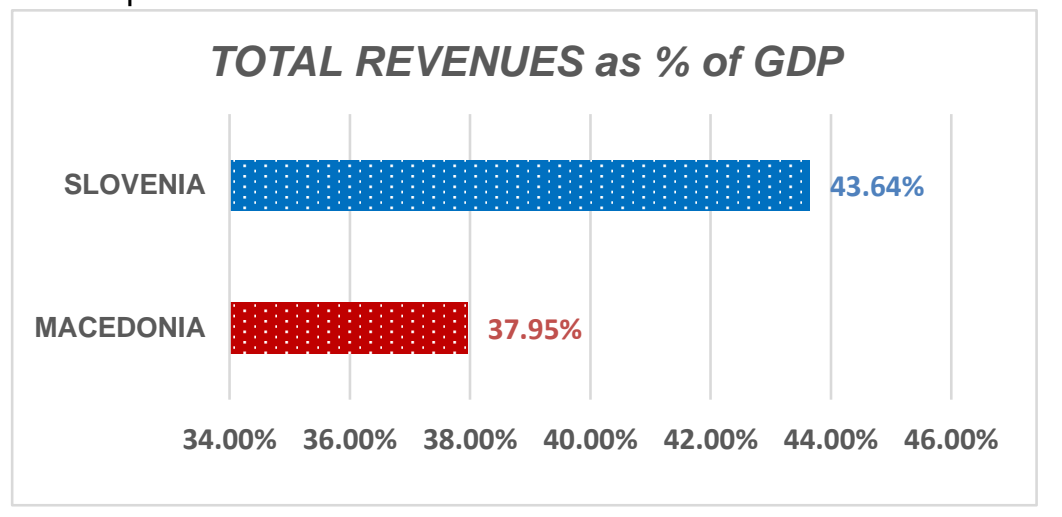

In 2008 the revenues of Slovenia represented higher percentage of GDP compared to the revenues of Macedonia. In addition, from the table, it can be concluded that in 2008, both Macedonia and Slovenia had the biggest revenue from taxes. Macedonia had higher percentage of non-tax revenue, donations received as well as capital revenue, while Slovenia had higher percentage of tax revenue as well as transferred revenues. In addition, only Slovenia had receipts from the EU budget since Macedonia is not member state of EU.

\subsubsection{Tax Revenues}

Table 4: Total Tax Revenues of Macedonia and Slovenia in 2008

\begin{tabular}{|l|r|r|}
\hline in euro & \multicolumn{1}{c|}{ MACEDONIA } & \multicolumn{1}{c|}{ SLOVENIA } \\
\hline TOTAL TAX REVENUE & $1,970,059,788.94$ & $13,937,364,572.81$ \\
\hline PERSONAL INCOME TAX & $141,398,373.98$ & $2,185,134,641.50$ \\
\hline CORPORATION TAX & $139,495,934.96$ & $1,257,036,956.17$ \\
\hline OTHER TAXES ON REVENUE AND PROFIT & $62,874,349.43$ & - \\
\hline SOCIAL SECURITY CONTRIBUTIONS & $621,934,959.35$ & $5,095,008,758.69$ \\
\hline TAXES ON PAYROLL AND WORKFORCE & - & $258,037,498.01$ \\
\hline TAXES ON PROPERTY & $32,645,727.53$ & $214,908,609.89$ \\
\hline DOMESTIC TAXES ON GOODS \& SERVICES & $820,308,943.09$ & $4,805,321,397.08$ \\
\hline TAXES ON INTERNATIONAL TRADE AND TRANSACTIONS & $102,032,520.33$ & $120,091,835.50$ \\
\hline
\end{tabular}

Graph 4: Total Tax Revenues of Macedonia and Slovenia in 2008

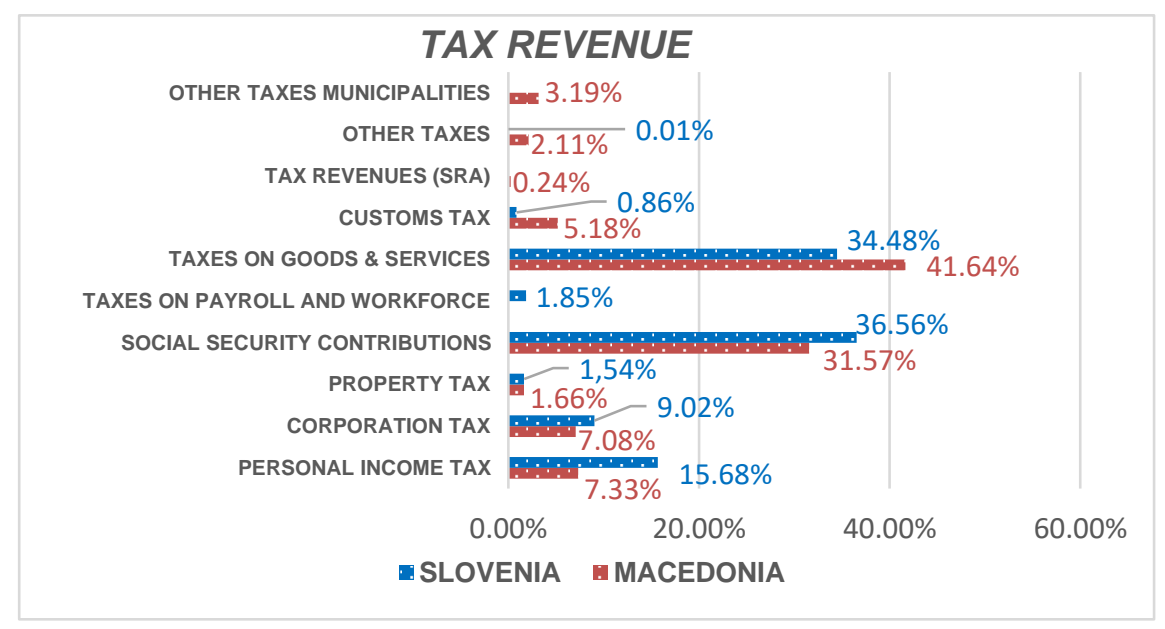

The tax revenue of both countries is composed of personal income tax which is double in Slovenia than in Macedonia, the corporation tax, the social security contributions which represent the highest tax revenue in Slovenia in 2008, the taxes on payroll and workforce was included only in the budget of Slovenia, the taxes on goods \& services which was the highest 
tax revenue in Macedonia, customs tax which is much higher in Macedonia compared to Slovenia because Macedonia is not member of the European Union and does not use the custom union rules.

\subsection{Taxes on Goods and Services}

Table 5: Total Taxes on Goods and Services of Macedonia and Slovenia in 2008

\begin{tabular}{|l|c|c|}
\hline in euro & MACEDONIA & SLOVENIA \\
\hline DOMESTIC TAXES On GOODS \& SERVICES & $820,308,943.09$ & $4,805,321,397.08$ \\
\hline VAT & $588,178,861.79$ & $3,144,500,933.47$ \\
\hline EXCISE & $232,130,081.30$ & $1,213,254,626.78$ \\
\hline MOTOR VEHICLE TAX & - & $71,444,021.41$ \\
\hline TAXES ON SPECIFIC SERVICES & - & $134,182,315.44$ \\
\hline ROAD USAGE FEE & - & $105,252,178.45$ \\
\hline $\begin{array}{l}\text { OTHER TAX ON THE USE OF GOODS \& } \\
\text { SERVICES }\end{array}$ & - & $106,666,100.72$ \\
\hline OTHER TAX ON GOODS \& SERVICES & - & $30,021,220.81$ \\
\hline
\end{tabular}

Graph 5: Total Taxes on Goods and Services of Macedonia and Slovenia in 2008

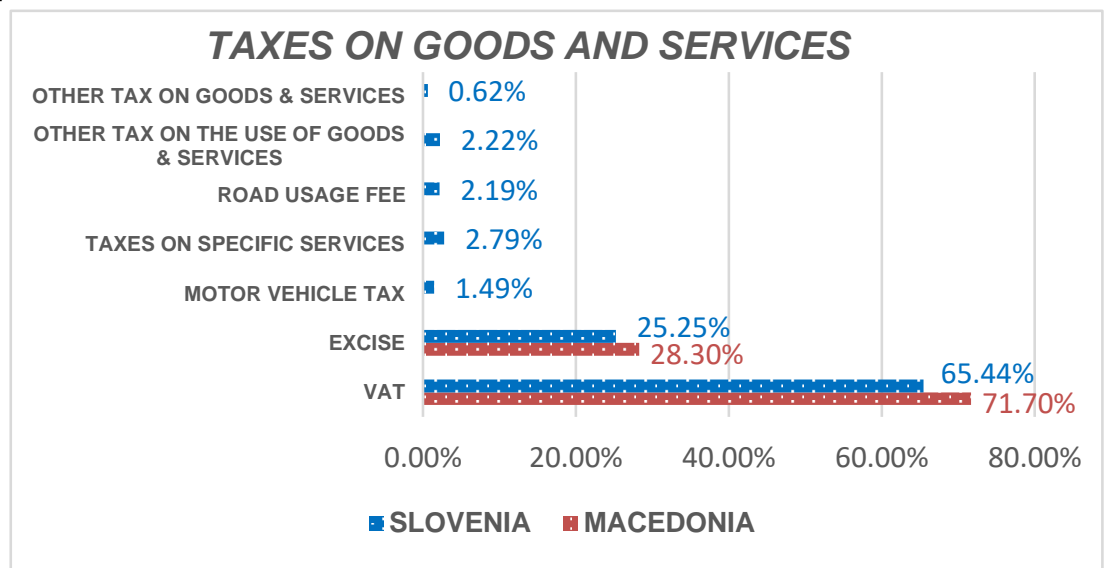

The Macedonian budget classifies the taxes on goods \& services only as an VAT and excise tax. Both of those taxes are higher in the Macedonian budget than in the Slovenian budget in 2008. As an addition Slovenia had five more types of taxes in the budget: motor vehicle tax, taxes on specific services, road usage fee, other taxes on goods \& services and other taxes on the use of goods \& services. All of those taxes are relatively small proportion compared to the VAT and excise taxes.

\subsubsection{Total Expenditures}

Table 6: Total Expenditures of Macedonia and Slovenia in 2008

\begin{tabular}{|l|c|c|}
\hline in euro & MACEDONIA & SLOVENIA \\
\hline TOTAL EXPENDITURE & $2,411,846,877.79$ & $15,441,743,040.52$ \\
\hline CURRENT EXPENDITURES AND TRANSFERS & $2,019,728,316.94$ & $13,299,727,779.99$ \\
\hline CAPITAL EXPENDITURES AND TRANSFERS & $392,118,560.85$ & $1,714,100,086.84$ \\
\hline PAYMENTS TO THE EU BUDGET & - & $427,915,173.69$ \\
\hline
\end{tabular}


Graph 6: Total Expenditures as \% of GDP of Macedonia and Slovenia in 2008

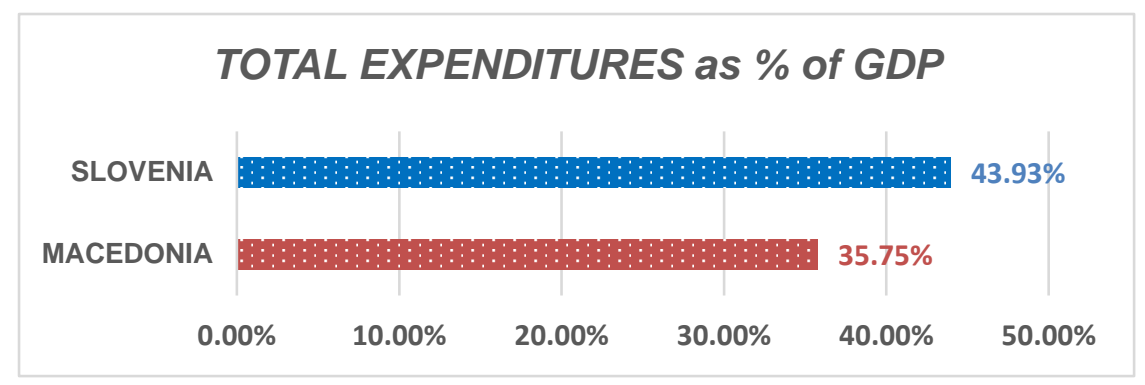

Graph 7: Total Expenditures of Macedonia and Slovenia in 2008

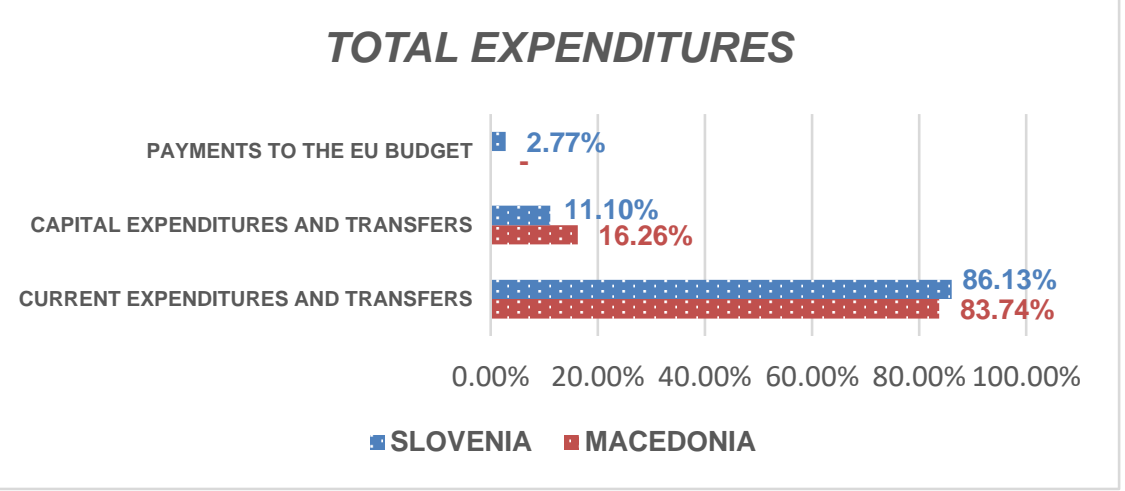

Same as the revenues, the total expenditures of Slovenia represent higher percent of GDP than of Macedonia. The total expenditures for Slovenia and Macedonia have two classifications current and capital expenditures plus payments to EU budget for Slovenia. Macedonia had approximately three quarters of the total expenditures as current expenditures. The rest were capital expenditure. On the other hand, Slovenia's current expenditures are not that high. Slovenia had current expenditure slightly higher than Macedonia. On the other hand, the capital expenditures and transfers are lower than in Macedonia.

\subsubsection{Current Expenditures}

Table 7: Total Current Expenditures of Macedonia and Slovenia in 2008

\begin{tabular}{|l|c|c|}
\hline in eurO & MACEDONIA & SLOVENIA \\
\hline TOTAL CURRENT EXPENDITURE & $1,953,821,138.21$ & $6,557,499,856.83$ \\
\hline WAGES AND OTHER PERSONNEL EXPENDITURE & $338,650,406.50$ & $3,036,671,616.12$ \\
\hline EMPLOYER'S SOCIAL SECURITY CONTRIBUTIONS & $1,267,349,593.50$ & $542,211,220.93$ \\
\hline PURCHASES OF GOODS AND SERVICES & $304,796,747.97$ & $2,527,471,783.77$ \\
\hline INTEREST PAYMENTS & $43,024,390.24$ & $335,166,296.61$ \\
\hline RESERVES & - & $115,978,939.40$ \\
\hline
\end{tabular}


Graph 8: Total Current Expenditures of Macedonia and Slovenia in 2008

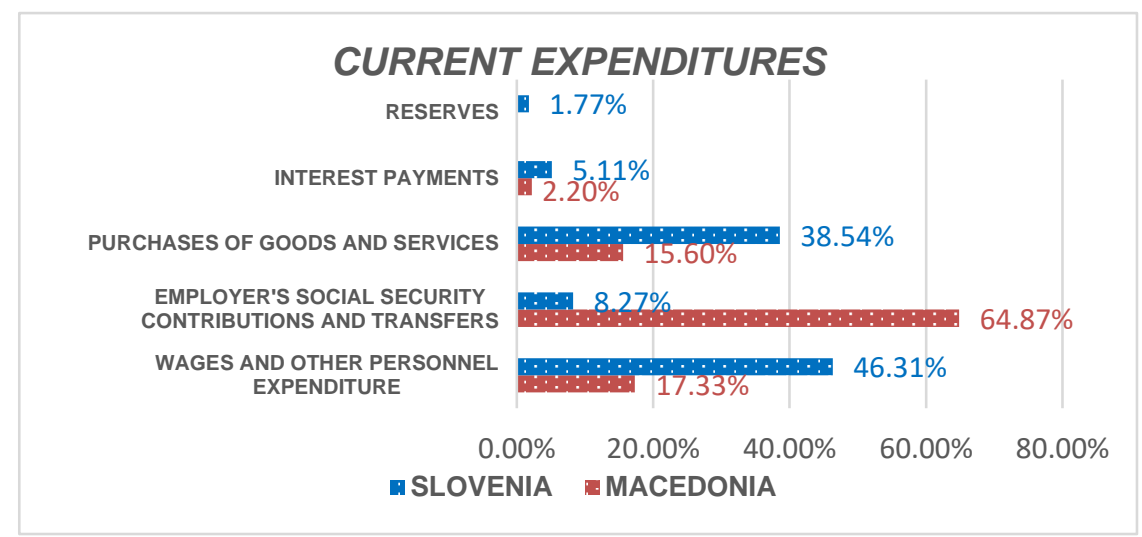

From Graph 8, it can be seen that Macedonian current expenditures were mainly employer's social security contribution and transfers. Another high percent were the wages and other personnel expenditures and the purchases of goods and services. On the other hand, Slovenia's highest expenditure were the wages and other personnel expenditure as well as the purchases of goods and services. Also, Slovenian budget had reserves classification unlike Macedonian. The interest payments are relatively small for both countries.

\subsection{Comparison of the Budgets between Macedonia and Slovenia in 2013}

\subsubsection{Budget Balance}

Table 8: Budget Balance of Macedonia and Slovenia in 2013

\begin{tabular}{|l|r|r|}
\hline in euro & \multicolumn{1}{|c|}{ MACEDONIA } & \multicolumn{1}{c|}{ SLOVENIA } \\
\hline TOTAL REVENUE & $2,737,971,747$ & $15,339,211,374$ \\
\hline TOTAL EXPENDITURE & $3,046,277,216$ & $15,441,743,041$ \\
\hline BUDGET BALANCE & $-308,305,468$ & $-102,531,667$ \\
\hline
\end{tabular}

Graph 9: Budget Balance of Macedonia and Slovenia in 2013

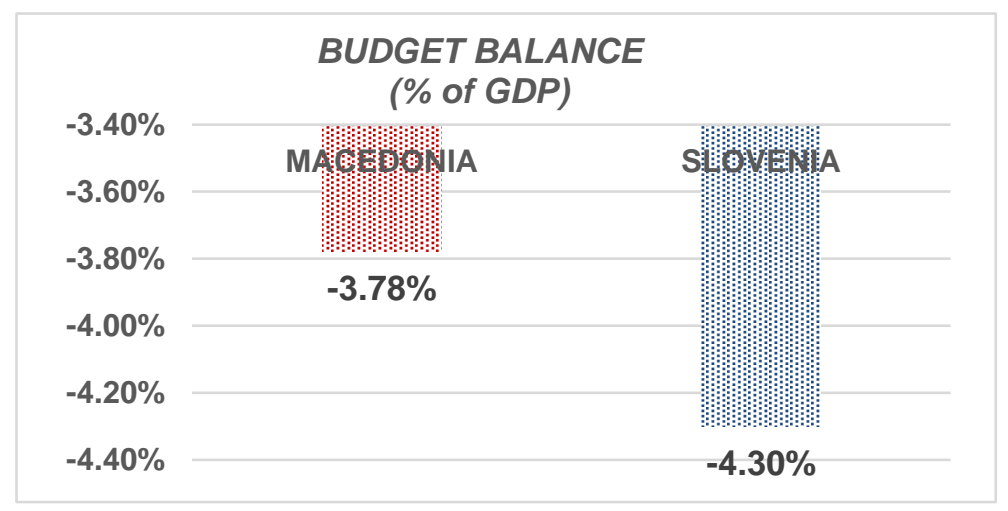

In 2013, both Macedonia and Slovenia were in budget deficit. However, Macedonia had deficit that was lower than the deficit of Slovenia. 


\subsubsection{Total Revenues}

Table 9: Total Revenues of Macedonia and Slovenia in 2013

\begin{tabular}{|l|r|r|}
\hline in euro & \multicolumn{1}{|c|}{ MACEDONIA } & \multicolumn{1}{c|}{ SLOVENIA } \\
\hline TOTAL REVENUE & $2,737,971,747.46$ & $15,339,211,373.57$ \\
\hline TOTAL TAX REVENUE & $2,076,693,338.34$ & $13,937,364,572.81$ \\
\hline NON-TAX REVENUE & $217,149,403.24$ & $854,903,347.53$ \\
\hline CAPITAL REVENUE & $87,159,812.67$ & $117,265,471.54$ \\
\hline DONATIONS RECEIVED & $336,947,471.51$ & $10,387,974.81$ \\
\hline TRANSFERED REVENUES & - & $53,916,240.72$ \\
\hline RECEIPTS FROM THE EU BUDGET & - & $365,373,766.16$ \\
\hline EVENUES FROM REPAYMENT OF LOANS & $9,073,170.73$ & - \\
\hline DOMESTIC BORROWING & $7,261,550.28$ & - \\
\hline FOREIGN BORROWINGS & $3,687,000.70$ & - \\
\hline
\end{tabular}

Graph 10: Total Revenues as \% of GDP of Macedonia and Slovenia in 2013

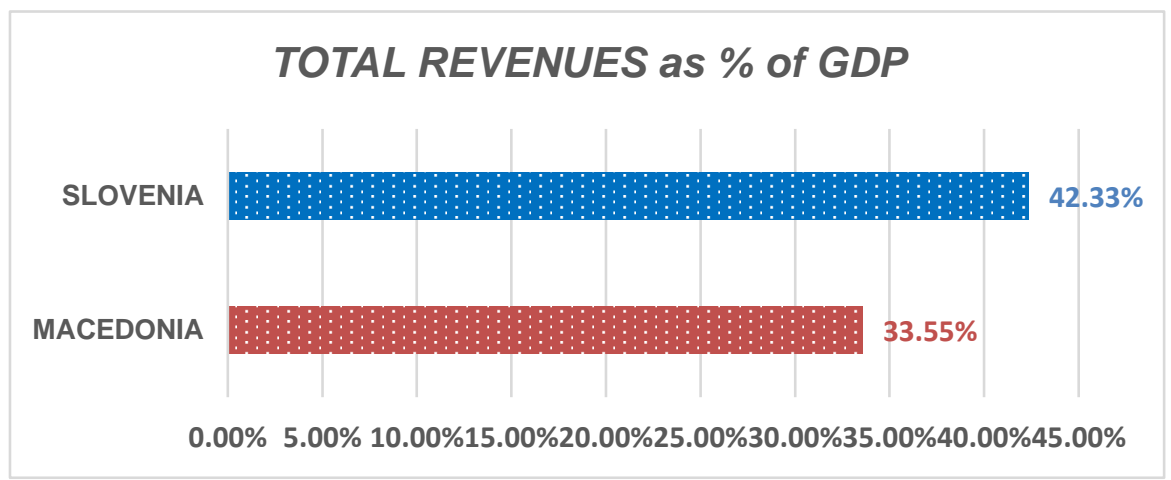

Graph 11: Total Revenues of Macedonia and Slovenia in 2013

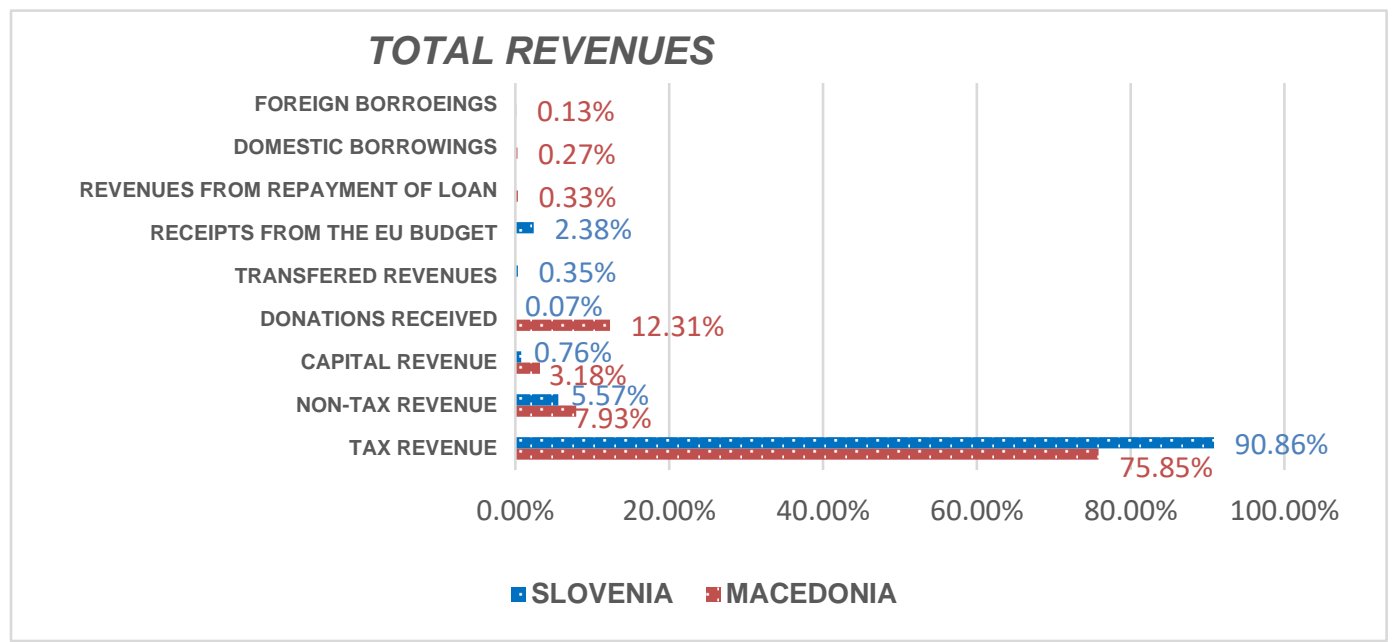

In 2013 again Slovenia had revenues with higher percent of GDP than Macedonia. Also, Macedonia and Slovenia generated highest revenue from taxes. The second source of revenue for Macedonia were the donations received from abroad and for Slovenia were the non-tax revenues such as capital gains, proceeds from sale of goods and services, administrative fees and more 


\subsubsection{Tax Revenues}

Table 10: Total Tax Revenues of Macedonia and Slovenia in 2013

\begin{tabular}{|l|r|r|}
\hline in euro & \multicolumn{1}{|c|}{ MACEDONIA } & \multicolumn{1}{c|}{ SLOVENIA } \\
\hline TOTAL TAX REVENUE & $2,076,693,338.34$ & $13,937,364,572.81$ \\
\hline PERSONAL INCOME TAX & $166,731,707.32$ & $2,185,134,641.50$ \\
\hline CORPORATION TAX & $71,886,178.86$ & $1,257,036,956.17$ \\
\hline OTHER TAXES ON REVENUE AND PROFIT & $67,334,051.06$ & - \\
\hline SOCIAL SECURITY CONTRIBUTIONS & $690,048,780.49$ & $5,095,008,758.69$ \\
\hline TAXES ON PAYROLL AND WORKFORCE & - & $258,037,498.01$ \\
\hline TAXES ON PROPERTY & $38,326,140.52$ & $214,908,609.89$ \\
\hline DOMESTIC TAXES On GOODS \& SERVICES & $907,723,577.24$ & $4,805,321,397.08$ \\
\hline TAXES ON INTERNATIONAL TRADE AND TRANSACTIONS & $69,186,991.87$ & $120,091,835.50$ \\
\hline
\end{tabular}

Graph 12: Total Tax Revenues of Macedonia and Slovenia in 2013

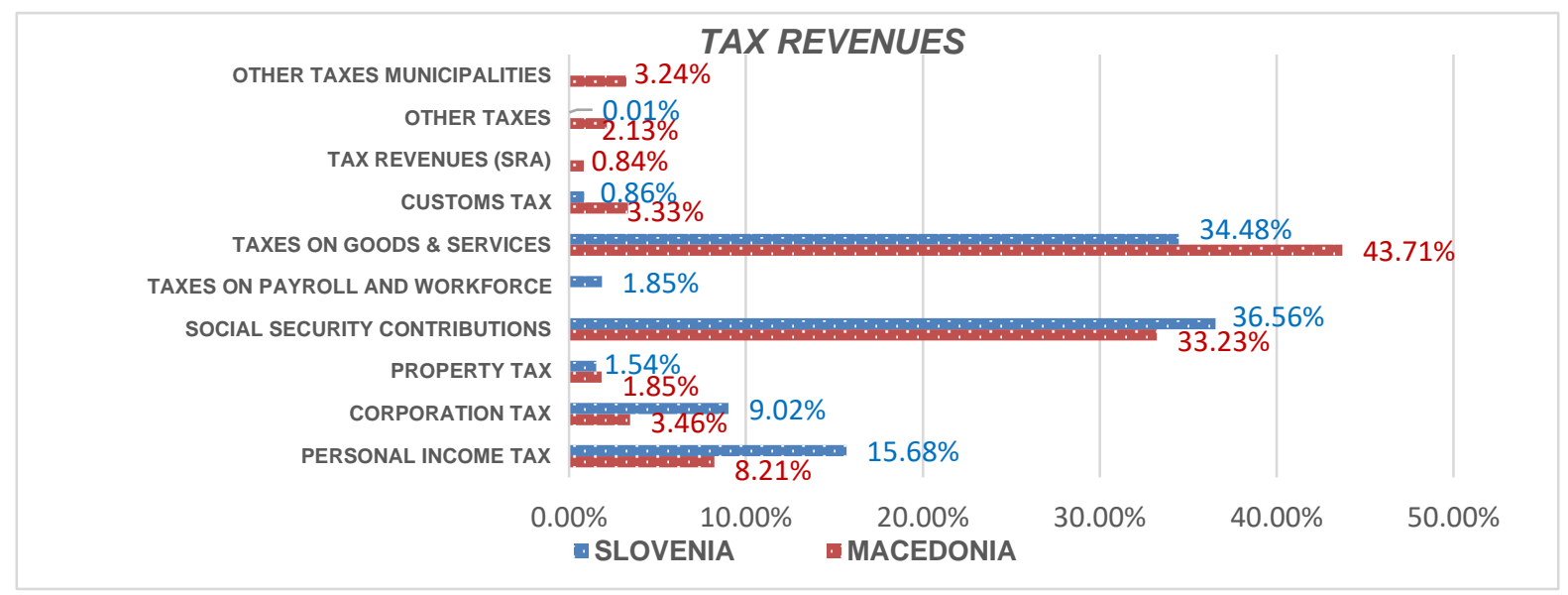

From Table 10 and Graph 12, it can be concluded that in 2013, Macedonia generated the highest tax revenues from taxes on goods and services (VAT and excise tax) while Slovenia from the social security contributions. Also, for both countries among the highest proportion is the personal income tax. There was a big difference in the customs tax between Macedonia and Slovenia. That is because Slovenia is part of the EU and has to follow their rules on lower or no custom duties for the EU member states.

\subsection{Taxes on Goods \& Services}

Table 11: Total Taxes on Goods and Services of Macedonia and Slovenia in 2013

\begin{tabular}{|l|c|c|}
\hline in euro & MACEDONIA & SLOVENIA \\
\hline TOTAL DOMESTIC TAXES On GOODS \& SERVICES & $907,723,577.24$ & $4,805,321,397.08$ \\
\hline VAT & $647,723,577.24$ & $3,144,500,933.47$ \\
\hline EXCISE & $260,000,000.00$ & $1,213,254,626.78$ \\
\hline MOTOR VEHICLE TAX & - & $71,444,021.41$ \\
\hline TAXES ON SPECIFIC SERVICES & - & $134,182,315.44$ \\
\hline ROAD USAGE FEE & - & $105,252,178.45$ \\
\hline OTHER TAX ON THE USE OF GOODS \& SERVICES & - & $106,666,100.72$ \\
\hline OTHER TAX ON GOODS \& SERVICES & - & $30,021,220.81$ \\
\hline
\end{tabular}


Graph 13: Total Taxes on Goods and Services of Macedonia and Slovenia in 2008

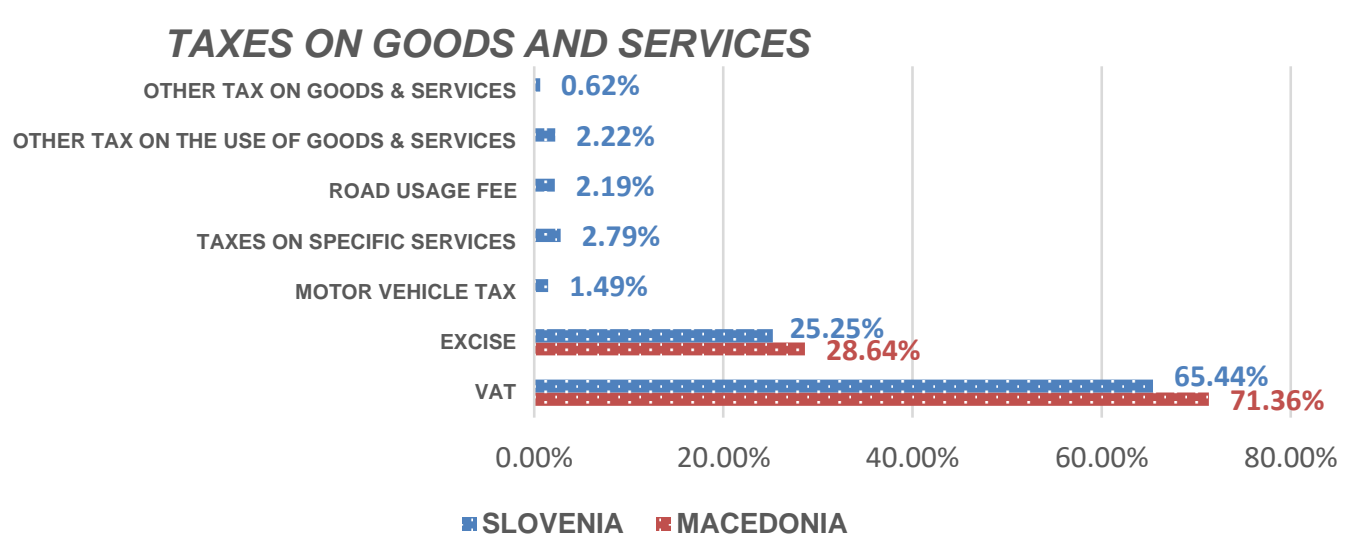

As in 2008, both Macedonia and Slovenia had higher revenues from taxes on goods and services from VAT and than from excise tax. In addition, in 2013, Slovenia had revenues from taxes on specific sevices as well as motor vehicle tax.

\subsubsection{Total Expenditures}

Table 12: Total Expenditures of Macedonia and Slovenia in 2013

\begin{tabular}{|l|l|r|}
\hline in eurO & MACEDONIA & \multicolumn{1}{l|}{ SLOVENIA } \\
\hline TOTAL EXPENDITURE & $3,046,277,215.84$ & $15,441,743,040.52$ \\
\hline CURRENT EXPENDITURES AND TRANSFERS & $2,679,147,696.93$ & $13,299,727,779.99$ \\
\hline CAPITAL EXPENDITURES AND TRANSFERS & $367,129,518.91$ & $1,714,100,086.84$ \\
\hline PAYMENTS TO THE EU BUDGET & - & $427,915,173.69$ \\
\hline
\end{tabular}

Graph 14: Total Expenditures as \% of GDP of Macedonia and Slovenia in 2013

TOTAL EXPENDITURES as \% of GDP

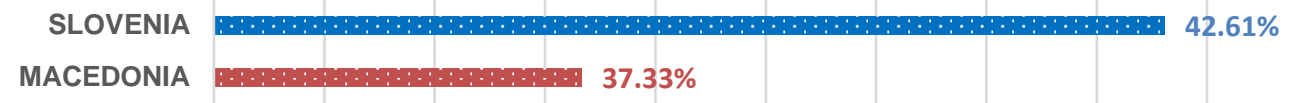

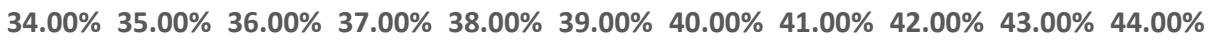

Graph 15: Total Expenditures of Macedonia and Slovenia in 2013

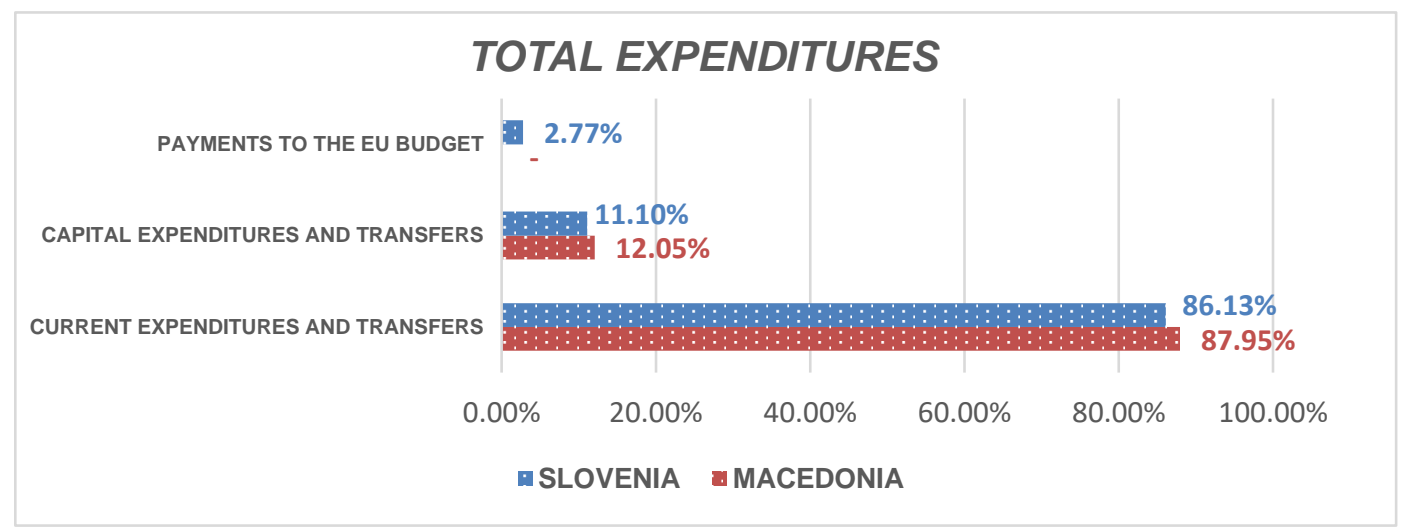


In 2013, Slovenia had expenditures that represent higher \% of GDP than Macedonia. In addition, the current expenditures of Macedonia were increased as opposed to the current expenditures in 2008. For Slovenia, the proportion of the expenditures remained the same as in 2008.

\subsubsection{Current Expenditures}

Table 13: Total Current Expenditures of Macedonia and Slovenia in 2013

\begin{tabular}{|l|r|r|}
\hline in eurO & \multicolumn{1}{|c|}{ MACEDONIA } & \multicolumn{1}{c|}{ SLOVENIA } \\
\hline TOTAL CURRENT EXPENDITURE & $2,323,479,674.80$ & $6,838,352,039.05$ \\
\hline WAGES AND OTHER PERSONNEL EXPENDITURE & $366,926,829.27$ & $3,113,656,857.95$ \\
\hline EMPLOYER'S SOCIAL SECURITY CONTRIBUTIONS & $1,639,756,097.56$ & $503,074,842.26$ \\
\hline PURCHASES OF GOODS AND SERVICES & $241,902,439.02$ & $2,238,919,509.61$ \\
\hline INTEREST PAYMENTS & $74,894,308.94$ & $840,086,497.45$ \\
\hline RESERVES & - & $142,614,331.78$ \\
\hline
\end{tabular}

Graph 16: Total Current Expenditures of Macedonia and Slovenia in 2013

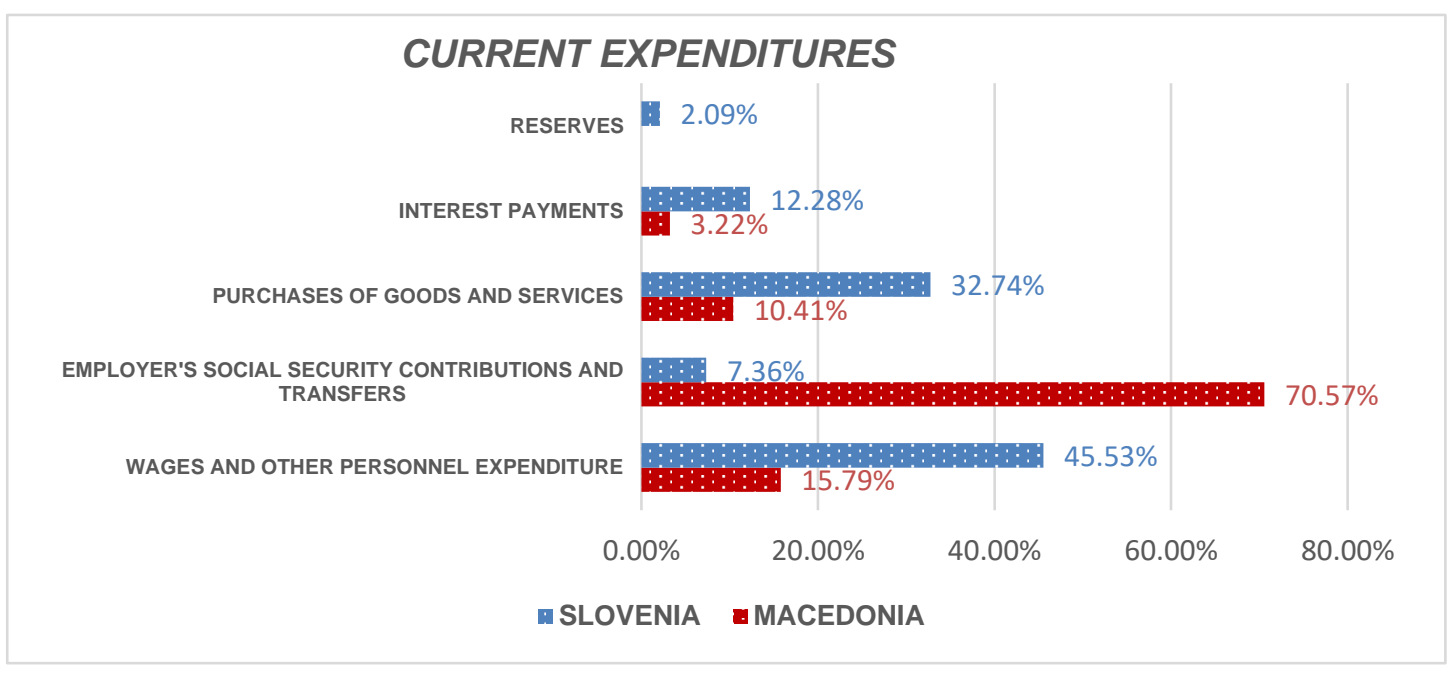

In 2013, the employer's social contributions and transfers were the highest current expenditure for Macedonia. In the other hand, in Slovenia the wages and other personnel expenditures were highest. Also, the purchases of goods and services hold high percent for both countries. In addition, Slovenia was the only country that had reserves in 2013.

\subsection{Comparison of the Budgets between Macedonia and Slovenia in 2017}

\subsubsection{Budget Balance}

Table 14: Budget Balance of Macedonia and Slovenia in 2017

\begin{tabular}{|c|c|c|}
\hline in euro & MACEDONIA & SLOVENIA \\
\hline TOTAL REVENUE & $3,423,056,766.62$ & $16,803,293,299.88$ \\
\hline TOTAL EXPENDITURE & $3,690,569,578.98$ & $17,101,978,420.01$ \\
\hline BUDGET BALANCE & $267,512,812.36$ & $298,685,120.13$ \\
\hline
\end{tabular}


Graph 17: Budget Balance of Macedonia and Slovenia in 2017

\begin{tabular}{|c|c|c|}
\hline \multicolumn{3}{|c|}{$\begin{array}{c}\text { BUDGET BALANCE } \\
(\% \text { of } G D P)\end{array}$} \\
\hline 0 & MAGEOONHA & SloveNA \\
\hline$-1.00 \%$ & & $\begin{array}{l}-0.69 \% \\
\end{array}$ \\
\hline$-1.50 \%$ & - & \\
\hline$-2.00 \%$ & & \\
\hline$-2.50 \%$ & - & \\
\hline$-3.00 \%$ & $-2.67 \%$ & \\
\hline
\end{tabular}

As opposed to 2013 when Slovenia had bigger budget deficit (as \% of GDP) than Macedonia, in 2017 it was opposite i.e., Macedonia had bigger deficit (as \% of GDP) than Slovenia. But if we compare the amounts, we can see that Slovenian deficit was higher.

\subsubsection{Total Revenues}

Table 15: Total Revenues of Macedonia and Slovenia in 2017

\begin{tabular}{|l|r|r|}
\hline in euro & \multicolumn{1}{|c|}{ MACEDONIA } & \multicolumn{1}{c|}{ SLOVENIA } \\
\hline TOTAL REVENUES & $3,423,056,766.62$ & $16,803,293,299.88$ \\
\hline TOTAL TAX REVENUES & $2,690,668,052.63$ & $15,162,006,415.85$ \\
\hline NON-TAX REVENUES & $239,214,868.47$ & $1,089,360,228.10$ \\
\hline CAPITAL REVENUES & $42,077,558.34$ & $91,166,433.18$ \\
\hline DONATIONS RECEIVED & $438,596,697.51$ & $9,498,619.14$ \\
\hline TRANSFERED REVENUES & - & $52,284,242.87$ \\
\hline RECEIPTS FROM THE EU BUDGET & - & $398,977,360.74$ \\
\hline REVENUES FROM REPAYMENT OF LOANS & $4,113,821.14$ & - \\
\hline DOMESTIC BORROWING & $8,378,333.43$ & - \\
\hline
\end{tabular}

Graph 18: Total Revenues as \% of GDP of Macedonia and Slovenia in 2017

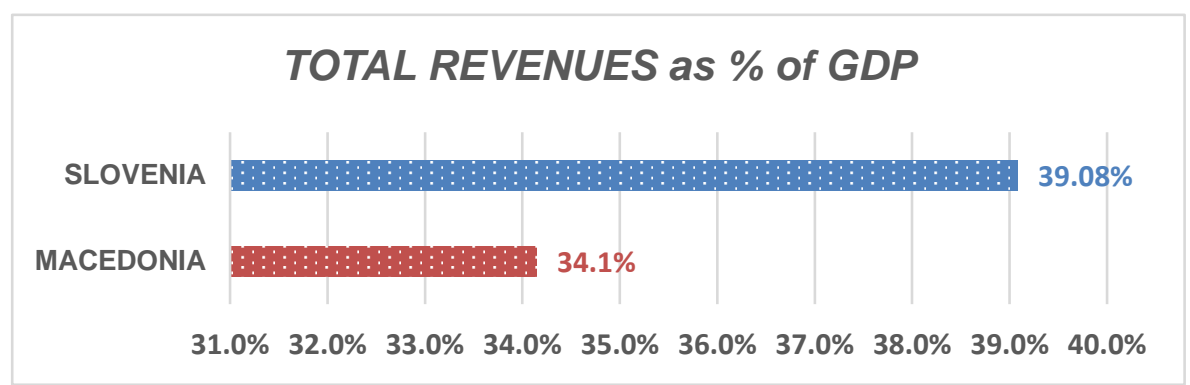


Graph 19: Total Revenues of Macedonia and Slovenia in 2017

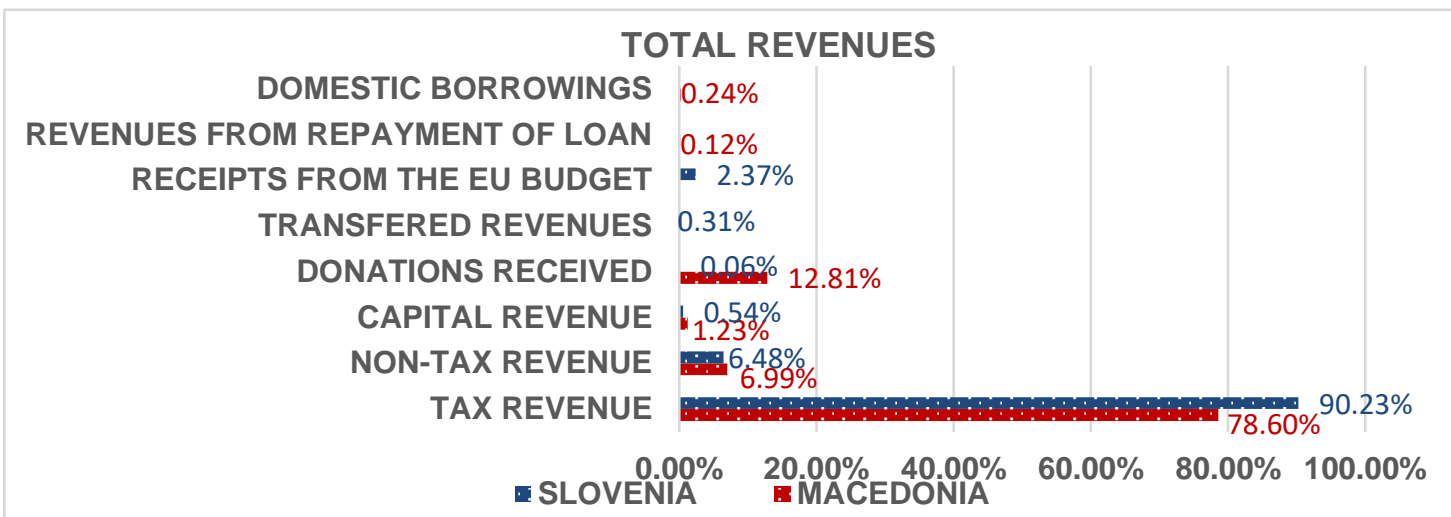

In 2017, the total revenue as percentage of GDP decreased in Slovenia and slightly increased in Macedonia compared to 2013. The situation with the total revenues structure in 2017 was pretty much the same as in the previous years with slight changes. For instance, for Macedonia, in 2017, the non-tax revenues slightly decreased and for Slovenia they slightly increased.

\subsubsection{Tax Revenues}

Table 16: Total Tax Revenues of Macedonia and Slovenia in 2017

\begin{tabular}{|l|r|r|}
\hline in eurO & \multicolumn{1}{|c|}{ MACEDONIA } & \multicolumn{1}{c|}{ SLOVENIA } \\
\hline TOTAL TAX REVENUE & $2,690,668,052.63$ & $15,162,006,415.85$ \\
\hline PERSONAL INCOME TAX & $248,178,861.79$ & $2,196,700,702.62$ \\
\hline CORPORATION TAX & $184,601,626.02$ & $766,269,558.76$ \\
\hline OTHER TAXES ON REVENUE AND PROFIT & $7,528,455.28$ & $3,988,289.95$ \\
\hline SOCIAL SECURITY CONTRIBUTIONS & $860,000,000.00$ & $6,092,096,588.29$ \\
\hline TAXES ON PAYROLL AND WORKFORCE & - & $21,341,890.63$ \\
\hline TAXES ON PROPERTY & $45,539,766.68$ & $274,233,567.46$ \\
\hline DOMESTIC TAXES On GOODS \& SERVICES & $1,153,869,918.70$ & $5,722,785,817.02$ \\
\hline TAXES ON INTERNATIONAL TRADE AND TRANSACTIONS & $84,146,341.46$ & $83,265,363.35$ \\
\hline
\end{tabular}

Graph 20: Total Tax Revenues of Macedonia and Slovenia in 2017

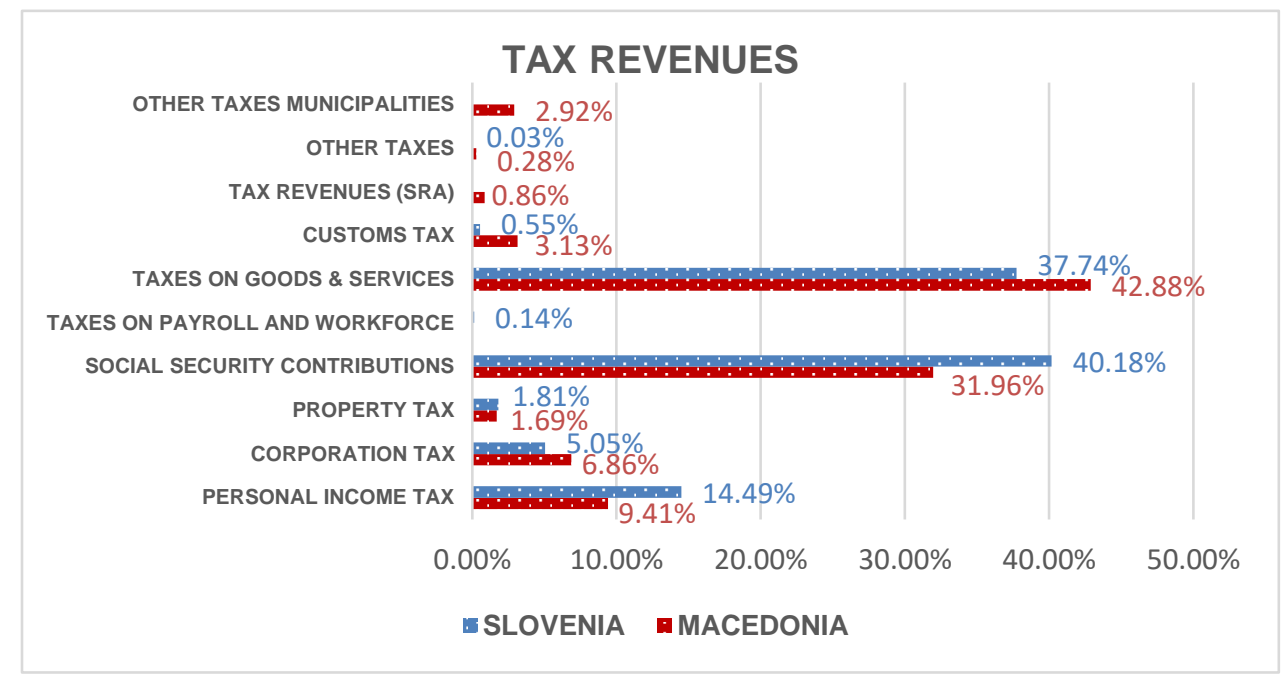

The tax revenues in 2017 compared to 2013 were changed just that the social contributions of Slovenia increased for about $4 \%$. In addition, the revenues from corporation tax of Macedonia increased for about 3\%. 


\subsection{Taxes on Goods \& Services}

Table 17: Total Taxes on Goods and Services of Macedonia and Slovenia in 2017

\begin{tabular}{|l|r|r|}
\hline in euro & \multicolumn{1}{|c|}{ MACEDONIA } & \multicolumn{1}{c|}{ SLOVENIA } \\
\hline DOMESTIC TAXES On GOODS \& SERVICES & $1,153,869,918.70$ & $5,722,785,817.02$ \\
\hline VAT & $778,373,983.74$ & $3,504,190,166.81$ \\
\hline EXCISE & $375,495,934.96$ & $1,585,476,381.25$ \\
\hline MOTOR VEHICLE TAX & - & $35,516,786.32$ \\
\hline TAXES ON SPECIFIC SERVICES & - & $215,567,704.73$ \\
\hline ROAD USAGE FEE & - & $152,036,905.81$ \\
\hline OTHER TAX ON THE USE OF GOODS \& SERVICES & - & $91,195,784.93$ \\
\hline OTHER TAX ON GOODS \& SERVICES & - & $138,802,087.17$ \\
\hline
\end{tabular}

Graph 21: Total Taxes on Goods and Services of Macedonia and Slovenia in 2017

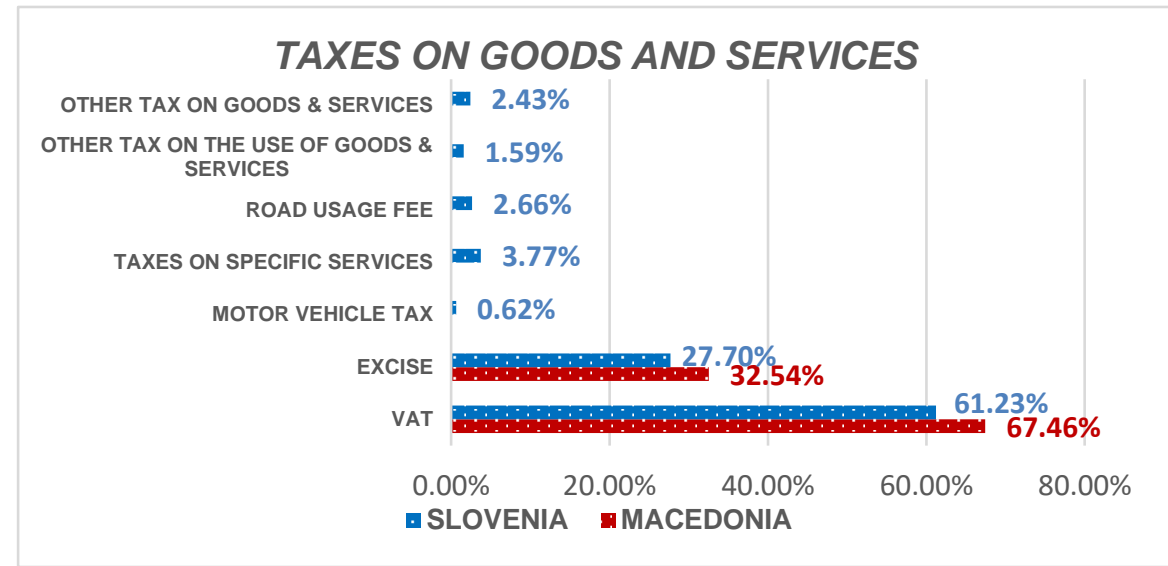

In 2017, the revenue generated from VAT, for both Macedonia and Slovenia decreased. On the other hand, the revenue from excise tax increased. In addition, the other taxes on goods and services in Slovenia increased for about $2 \%$ compared to 2013 . Everything else was with no significant changes.

\subsubsection{Total Expenditures}

Table 18: Total Expenditures of Macedonia and Slovenia in 2017

\begin{tabular}{|l|r|r|}
\hline in eurO & \multicolumn{1}{|c|}{ MACEDONIA } & \multicolumn{1}{l|}{ SLOVENIA } \\
\hline TOTAL EXPENDITURE & $3,690,569,579$ & $17,101,978,420$ \\
\hline CURRENT EXPENDITURES AND TRANSFERS & $3,259,703,544$ & $15,404,265,377$ \\
\hline CAPITAL EXPENDITURES AND TRANSFERS & $430,866,035$ & $1,077,621,825$ \\
\hline PAYMENTS TO THE EU BUDGET & & $378,498,464$ \\
\hline
\end{tabular}

Graph 22: Total Expenditures as \% of GDP of Macedonia and Slovenia in 2017

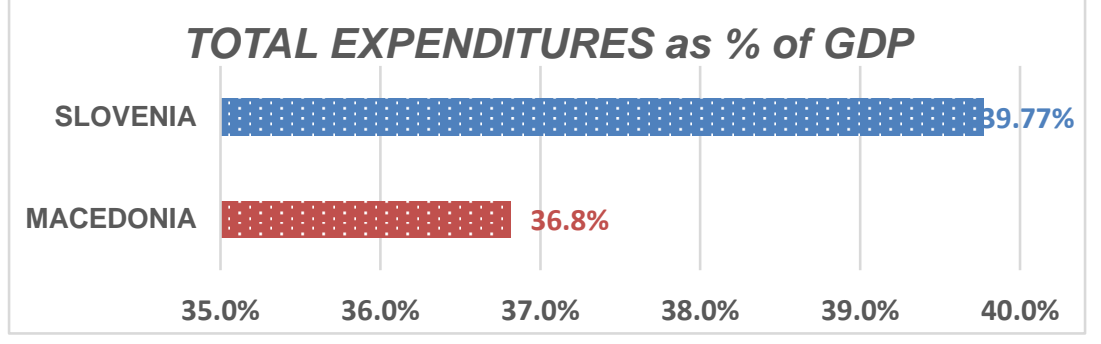


Graph 23: Total Expenditures of Macedonia and Slovenia in 2017

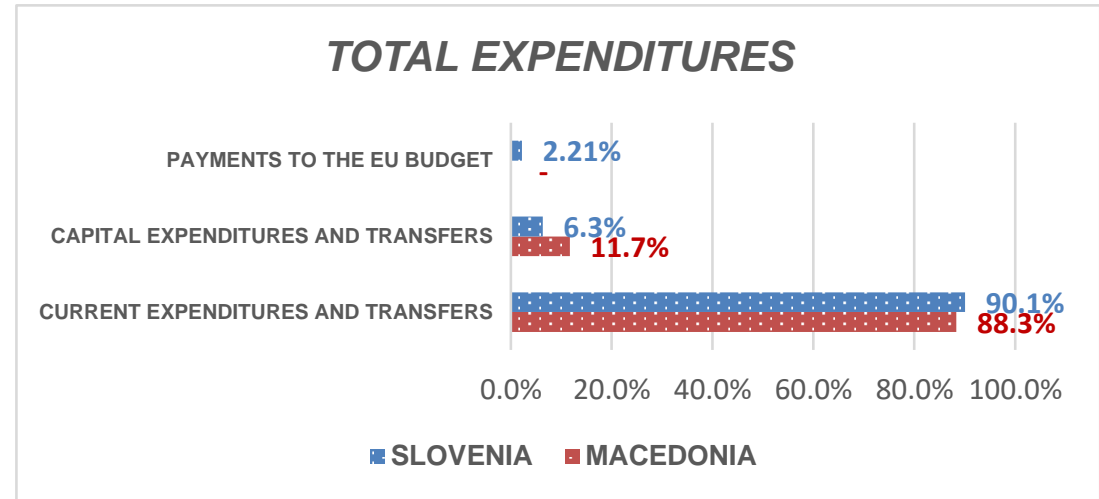

For both Macedonia and Slovenia, in 2017, the expenditures as percentage of GDP increased compared to 2013. In addition, the current expenditures continued to increase and the capital expenditures continued to decrease. Also, for Slovenia, the current expenditures increased while both the capital expenditures as well as the EU budget transfers slightly decreased.

\subsubsection{Current Expenditures}

Table 19: Total Current Expenditures of Macedonia and Slovenia in 2017

\begin{tabular}{|l|r|r|}
\hline \multicolumn{1}{|c|}{ in euro } & \multicolumn{1}{c|}{ MACEDONIA } & \multicolumn{1}{c|}{ SLOVENIA } \\
\hline TOTAL CURRENT EXPENDITURE & $2,873,138,211.38$ & $7,733,007,079.64$ \\
\hline WAGES AND OTHER PERSONNEL EXPENDITURE & $426,081,300.81$ & $3,405,562,785.53$ \\
\hline EMPLOYER'S SOCIAL SECURITY CONTRIBUTIONS & $2,061,170,731.71$ & $532,515,962.65$ \\
\hline PURCHASES OF GOODS AND SERVICES & $249,495,934.96$ & $2,626,598,553.43$ \\
\hline INTEREST PAYMENTS & $136,390,243.90$ & $985,305,939.89$ \\
\hline RESERVES & - & $183,023,838.14$ \\
\hline
\end{tabular}

Graph 24: Total Current Expenditures of Macedonia and Slovenia in 2017

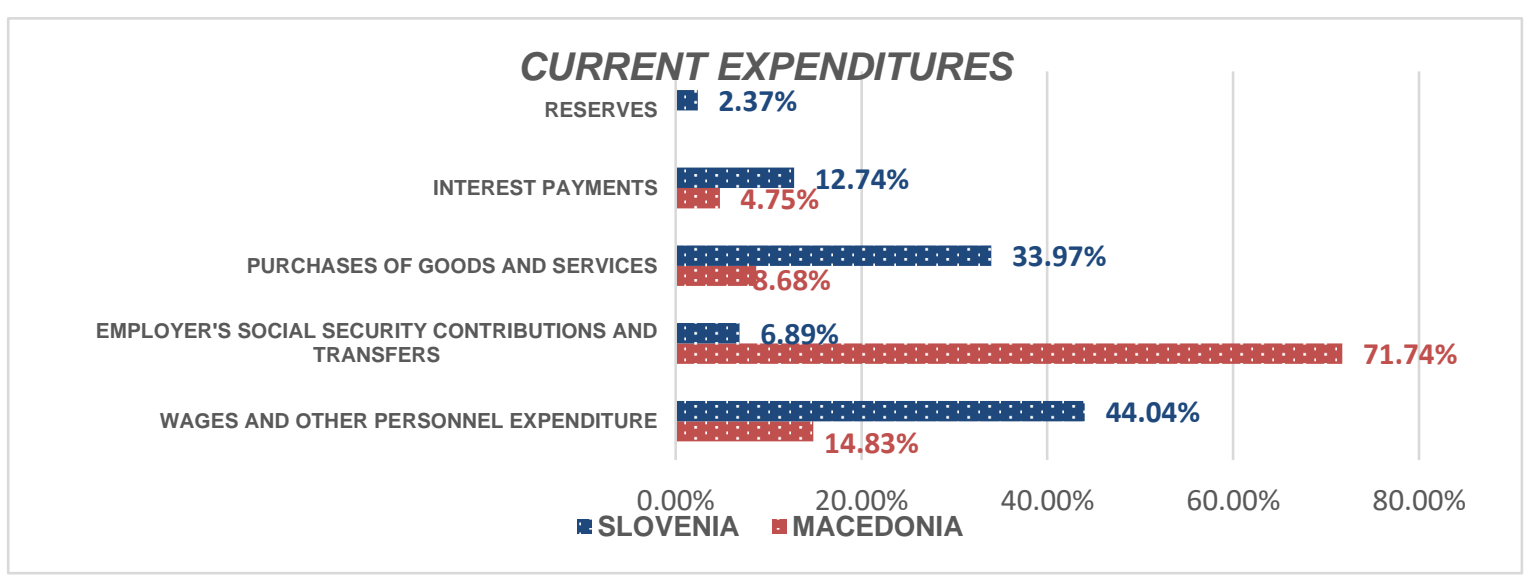

In 2017, the wages and other personnel expenditures slightly decreased for both countries. On the other hand, the interest payments increased. Also, the employer's social security contributions and transfer were increasing in Macedonia but decreasing in Slovenia. 


\section{CONCLUSION}

After analysing the budgets of both countries for the years 2008, 2013 and 2017, the conclusion is that the procedure for adopting the budget and the classification of the budget is identical in both countries. One difference is that the budget of Slovenia is adopted for two fiscal years and the budget of Macedonia is adopted for one fiscal year. In addition, both countries have similar revenues and expenditures structures. For instance, in both Slovenia and Macedonia the taxes are the highest revenue source and the current expenditures are also the highest. Also, as presented in this paper, Slovenia has several times bigger amounts of budget positions than the positions of the Macedonian budget, which points to the conclusion that Slovenia is a significantly more economically developed and politically more stable country.

\section{REFERENCES}

1. GUIDE TO BUDGETS (2006). Foundation Fredrich Ebert Stiftung, pg.13. Retrieved from: http://www.crpm.org.mk/wp-content/uploads/2012/03/VodicvobuzetiMKD.pdf [Accessed 2 May 2019].

2. HANDBOOK FOR BUDGET AND BUDGET PROCESS (2018). 2nd edition. Skopje: Center for Economic Analyses, pg.10. Retrieved from: https://cea.org.mk/wpcontent/uploads/2018/04/TSEA-prirachnik-FINAL-FINAL-2018.pdf [Accessed 2 May 2019].

3. BUDGET LAW. Ministry of Finance (n.d.). Retrieved from: https://finance.gov.mk/files/u6/ 5.pdf [Accessed 3 May 2019].

4. GUIDE TO BUDGETS (2006). Foundation Fredrich Ebert Stiftung. Retrieved from: http://www.crpm.org.mk/wp-content/uploads/2012/03/VodicvobuzetiMKD.pdf [Accessed 2 May 2019].

5. BUDGET LAW. Ministry of Finance (n.d.) pg. 17. Retrieved from: https://finance.gov.mk/files/u6/ 5.pdf. [Accessed 3 May 2019].

6. HANDBOOK FOR BUDGET AND BUDGET PROCESS (2018). 2nd edition. Skopje: Center for Economic Analyses. Retrieved from: https://cea.org.mk/wp-content/uploads/2018/04/TSEAprirachnik-FINAL-FINAL-2018.pdf [Accessed 2 May 2019].

7. General for the budget. Ministry of Finance Slovenia [online]. Retrieved from: http://www.mf.gov.si/si/delovna_podrocja/proracun/splosno_o_proracunu/ [Accessed 6 May 2019].

8. BUDGETING IN SLOVENIA. (2019). Organisation for Economic Co-operation and Development (OECD). Pg.6. Retrieved from: https://www.oecd.org/slovenia/39997582.pdf [Accessed 6 May 2019].

9. PARLIAMENTARY BUDGETING IN HUNGARY AND SLOVENIA (2000). Washington State University, pg.12. Retrieved from: https://www.internationalbudget.org/wpcontent/uploads/Parliamentary-Budgeting-in-Hungary-and-Slovenia.pdf [Accessed 7 May 2019].

10. COMPONENT PARTS OF THE BUDGET. Ministry of Finance Slovenia. (n.d.). [online]. Retrieved from: http://www.mf.gov.si/si/delovna_podrocja/proracun/splosno_o_proracunu/sestavni_deli_proracun a/ [Accessed 6 May 2019].

11. BUDGET SYSTEM AND BUDGET PREPARATION PROCEDURES IN SLOVENIA. (2011). Ministry of Finance Slovenia. Retrieved from: https://www.pempal.org/sites/pempal/files/event/attachments/3a_volj-_budget-system-and- 
budget-preparation-procedures-in-slovenia_eng.pdf. [Accessed 7 May 2019]. 